DOI 10.14746/ssp.2021.1.6

\title{
Nataliia Kнома
}

Lviv Polytechnic National University

ORCID: 0000-0002-2507-5741

Ihor VDOVYCHYN

Ivan Franko National University of Lviv

ORCID: 0000-0002-3210-7684

\section{EU Policy on Deepening Liberal Democracy: A Case Study of the Baltic States}

\begin{abstract}
The issues of the EU's activities concerning the quality of democracy in member states are studied. On the examples of Estonia, Latvia and Lithuania, the effectiveness of EU projects to continue the liberal-democratic transformation in member states with a post-totalitarian past where the risk of regression of democracy remains, is assessed. The current goals of the EU are described as being insufficient in terms of properly preventing and counteracting the decline of the quality of democracy, as well as for inculcating the values of liberal democracy. The need to intensify the EU's activities in the direction of monitoring the observance of democratic standards is explained by the stagnation/regression of the quality of democracy in the countries of the recent EU enlargements, including the Baltic States. The actions of the EU's institutions towards member states, where democracy shows stagnation/regression, are assessed as inconsistent, due to the possible consequences of this destructive process. The EU's lack of attention to strengthening the values on which the EU is based is emphasized, which is seen as the main reason for the present deterioration in the quality of democracy. The requirement to construct a new format of European democracy and new mechanisms to ensure its quality is highlighted.
\end{abstract}

Key words: liberal democracy, Baltic States, EU, defects of democracy, quality of democracy

\section{Introduction}

7 he EU was created as a union of states based on the values of respect 1 for human dignity, freedom, democracy, equality, the rule of law and others. Article 2 of the Treaty on European Union (1992) suggests that these values are common to member states within a community 
that must be characterized by pluralism, non-discrimination, tolerance, justice, gender equality, and so on. Nevertheless, the political processes of the last two decades demonstrate that the liberal-democratic values, which are fundamental to the EU, are losing their stability in member states. Intolerance, the language of hostility, numerous social phobias, and so on, are on the rise in the communities of the EU states (first of all, in the "young" democracies of the fifth and subsequent stages of EU enlargement). In the conditions of greater diversity of the EU, intolerance, various forms of discrimination and other defects of democracy are growing.

In the face of such new challenges, upholding the values of pluralism, tolerance and non-discrimination should be of particular importance to European institutions. The EU is expected to intensify the democratization processes of the "young" democracies in Central and Eastern Europe. These states made great efforts in the late 1990s and early 2000s to meet the Copenhagen criteria, but since May 1, 2004, there has been stagnation and sometimes regression in the processes of liberal democratization, and the EU, according to our estimates, is not making appropriate efforts to consistently continue democratic transformations or to prevent a decline in the quality of democracy.

The Baltic States (Estonia, Latvia and Lithuania) are part of this destructive process within the EU, even though the deterioration in the quality of democracy here is less obvious than in most other Central and Eastern European countries. Simultaneously, in the Baltic States, the processes qualifying as the "stagnation/regression of the quality of democracy" are increasing, and therefore they need to be studied. The Baltic States, which share a common historical past, have suffered similar historical traumas and are now manifesting common institutional and value barriers to the further intensification of democratization processes and maximum convergence with EU standards.

Each of the Baltic States demonstrates a distinct approach to the issues of liberal democratization, which arises from the coming to power of certain political forces, greater or lesser public support for certain issues, consistency/inconsistency of the heads of states in promoting EU policy at the national level, and so on. It is the processes of stagnation/ regression of democracy in the Estonian, Latvian and Lithuanian politics in 2004-2020, as well as the EU's position on this issue, that are of considerable research interest. 


\section{The Latest EU Priorities and Their Place in the System of Democracy Quality Issues}

In 2019-2020, anti-liberal political forces gained substantial support in EU member states. A rising number of leaders in Central and Eastern Europe refuse even to feign playing by the rules of democracy. The quality of democracy continues to deteriorate every year in many member states, including the Baltic States, most notably Lithuania and Latvia.

Simultaneously with the depreciation of the quality of democracy in the EU, new priorities for a united Europe have emerged. These are set out in a number of EU documents, among which we should highlight, first of all, the Rome Declaration, 2017. The text of the declaration emphasizes the goals of constructing a safe and reliable community of the peoples of Europe, which will be competitive, sustainable and socially responsible, with the expressed desire and ability to play a leading role in the world. The EU has assigned itself a task to build a community of states where citizens have new opportunities for economic growth, cultural and social development. However, the realization of such lofty goals has been postponed due to the coronavirus pandemic, but their setting remains relevant against the background of this latest challenge.

The text of the Rome Declaration of the EU (Council of the EU, 2017) defines the goals of the EU for the coming years:

1) a safe and secure Europe. This is an EU where all citizens feel safe; freedom of movement is guaranteed; external borders are properly guarded; an effective, responsible and sustainable migration policy with respect to the norms of international law is implemented; a process of prevention and counteraction of terrorism, organized crime is properly organized;

2) a prosperous and sustainable Europe. It is assumed that in the EU conditions are established for economic growth and job creation; there is a strong interconnected developing market that embraces technological transformation; the single currency is steadily strengthening; the purposes of stable and sustainable growth are accomplished through investment, structural reforms; work on the creation of an economic and monetary union is completed; energy is safe and affordable, and the environment is clean and safe.

3) a social Europe. The task here is to further evolve the EU on the basis of sustainable economic growth which contributes to economic and social progress; to take into account the diversity of national systems 
and the key role of social partners, including trade unions; to ensure equality between women and men, rights and equal opportunities for all; to combat unemployment, discrimination, social exclusion and poverty; to provide opportunities for good education to young people, opportunities to study and find work across the European continent; to preserve cultural heritage and promote cultural diversity;

4) a stronger Europe on the global stage. This means: to further develop existing EU partnerships, to build new ties and strengthen the stability and prosperity of the EU's nearest neighbors in the east and south, as well as in the Middle East, Africa and around the world; to undertake more responsibility by the EU and contribute to the creation of a more competitive and integrated defense industry; to reinforce overall security and defense, in particular in cooperation and complementarily with NATO, taking into account national specificities and legal obligations; to cooperate with the UN and uphold the basic rules of the multilateral system, to preserve its values, promote free and fair trade, a positive global climate policy.

On the basis the study of the Rome Declaration of the EU, we make the assumption that today the task of improving the quality of democracy, promoting the democratization of the last "waves" of its expansion is not a priority for the EU. Among the aspects that fall within the range of the quality of democracy and strengthening the stability of liberal democracy, the Rome Declaration of the EU focuses only on the goal of achieving a higher level of gender equality and preventing social exclusion, as well as a responsible migration policy. Simultaneously, numerous issues of the quality of democracy and the compliance of member states with the characteristics of liberal democracy remain ignored by EU institutions. It is noticeable that in recent years the priority has shifted to security issues. The idea of supporting democracy at the EU level, in our opinion, no longer functions as a comprehensive factor that unites EU member states. It is probable that the problem of slowing down the pace of democratization by a group of Baltic States and compliance with the standards of democracy which the EU is actually guided by is rooted in the decreased attention of the EU itself.

On May 9, 2019, at an informal summit in the Romanian city of Sibiu, the Sibiu Declaration was adopted - a strategy for action of EU member states for the next five years (Council of the EU, 2019). Emphasis was placed on joint action for the sake of the EU's perspective, protection of democracy and the rule of law in its territories, and adherence to 
common values (liberal-democratic in nature). During the summit, the topic of democracy and its values was not clearly highlighted and was presented briefly. The topic of the quality of democracy was supplanted by the discussion of the issues of digital transformation, climate change, environmental protection, maintenance and development of the international order, investment in youth and others.

Currently, it is apparent that the EU's ability to act to reinforce democracy in the international arena is being undermined by numerous attacks on democratic regimes (both from outside and inside) by stakeholders in individual EU member states. Already 10-12 years ago, some EU member states clearly displayed a lack of consistency with democratic standards and did not show the political will to enhance liberal-democratic transformations. In the first place, this refers to the EU member states of the latest enlargements (from 2004). Today, a number of these states further question the need to focus on the standards of liberal democracy, alternatively demonstrating a commitment to conservative, nationalist or other values. An example, first of all, is Hungary, where Victor Orbán is introducing a conservative Christian democracy. This is despite the fact that on the eve of accession to the EU, these countries met the Copenhagen criteria (particularly, the group of political criteria).

The assumption (the probability of which, however, requires a separate study) is that in order to join the EU, some candidate countries, wishing to receive benefits from their future EU membership, to some extent concealed their true attitude to the liberal-democratic values of the EU. In such a situation, it is expected that the EU should now pay much more attention to the projects that are aimed at improving the quality of democracy both within the EU as a whole and in individual member states, where one or another aspect of the problem of democracy quality is particularly acute.

We believe that the positions of individual EU member states have to some extent eroded Europe's long-standing commitment to democracy and human rights. In such circumstances, the EU displays, in our view, a lack of activity in promoting democratic reforms and monitoring the specific areas of deepening democratic transformation in the countries of the recent EU enlargements.

It is worth noting that the EU has never been particularly inclined to impose harsh sanctions for the benefit of democratic stability. As of 2019, the EU has applied about forty different sanctions altogether (Raine, 2019 , p. 122). This is with reference to a wide range of EU restrictions 
imposed on various global actors, not only EU member states. Examples are the sanctions caused by the nuclear program of Iran; sanctions against the Russian Federation owing to the annexation of Crimea; sanctions conditioned by the outbreak of the civil war in Syria, and so on. Despite the fact that these measures were directed against undemocratic regimes and thus contained a pro-democratic component, the deviation from the values of liberal democracy was not the direct reason for these EU sanctions, as the priority was (from our standpoint) the values of international security and stability, rather than liberal democracy, even though they are interdependent.

At present, in terms of the sanctions caused by the anti-democratic actions of European governments, the EU is paying more and more attention to European states outside the EU than to member states. The latter are perceived as states that seem to have coped with the major undemocratic manifestations. The argument in favor of this hypothesis is the states of the Balkan Peninsula from 2018 (Bosnia and Herzegovina, Serbia, and Montenegro).

It is important to note that even if the EU responds with sanctions to the problems of democracy in the world, it still has a wide range of cases of cooperation, especially in the sphere of trade, with neo-authoritarian states (Azerbaijan, Belarus, China, Cuba, Egypt, Morocco, Serbia and others). Business pragmatism appears to displace the lofty goals of liberal-democratic progress.

By means of numerous financial instruments, the EU has been gradually increasing its democratic assistance in places where new opportunities for the establishment of liberal democracy standards have emerged in recent years: Armenia, Fiji, Myanmar, Tunisia and others. Nonetheless, does such "dispersion" not affect the quality of cooperation to strengthen the quality of democracy in the last "waves" of EU enlargement? It is the states with undemocratic regimes that have received significant amounts of aid from the EU: in 2013-2017 alone, 84 percent of various types of development aid was directed not to the states of the latest "waves" of EU enlargement, but to the states with neo-authoritarian or hybrid political regimes. The amount of 2.88 billion US dollars was allocated to support democratization in countries with neo-authoritarian regimes; 6.59 billion US dollars - to countries with hybrid regimes; 1.8 billion US dollars - to defective democracies; and 0.03 billion US dollars - to full democracies (Godfrey, Youngs, 2019, p. 6). Understandably, by supporting democratic initiatives, especially in neo-authoritarian and hybrid regimes, the EU 
wants to solidify its image as a flagship of democracy, but it is apparent that the flagship itself has slowed down in its democratic progress.

After May 1, 2004, the EU's primary task was to assist the new EU member states in catching up with the long-established member states. It is remarkable that the chief goal was to promote the equalization of member states in terms of growth rates and income levels, rather than the effectiveness of democratic reforms. For example, since 2014, this task has been implemented through the agency of the European Fund for Strategic Investments (EFSI), or the Juncker Plan. Its major objective is to increase investment to create new jobs, remove obstacles to investment, and provide technical assistance to investment projects. The major objective is aimed at reforms in the member states which would make them attractive to investors, businesses and the public. However, the implementation of this project has been severely criticized. Hence, we observe which issues have become a priority: the problems of consolidating democratic reforms at the institutional or value level are not included here.

\section{EU Democracy Support Projects in the Baltic States (2004-2020)}

Let us identify which EU projects to support democratization at the institutional and value levels have been implemented for Estonia, Latvia and Lithuania since their accession to the EU in 2004.

In 2004-2020, European Structural and Investment Funds invested 18.1 billion euros in Lithuania; another 1.6 million euros of additional investment was attracted by Lithuania under the Juncker Plan for the period from 2014. During the six years of operation of the European Fund for Strategic Investments, 10,750 small and medium-sized enterprises in Lithuania were supported. The key investment results are: the construction and modernization of $445 \mathrm{~km}$ of railways and 1,659 $\mathrm{km}$ of roads, assistance to 1,468 research projects, active development of renewable energy, and so on. (European Commission, 2019c). In 2014-2020, Lithuania received 54.2 million euros under Horizon 2020 - the EU Framework Program for Research and Innovation.

Concerning the case of Latvia, in 2004-2020 European Structural and Investment Funds invested 12.2 billion euros in this country; another 1 million euros of additional investment was attracted by Latvia under the Juncker Plan for the period from 2014 (European Commission, 2019b). The European Fund for Strategic Investments supported 12,187 small 
and medium-sized enterprises in Latvia. In 2014-2020, Latvia received 56.6 million euros under Horizon 2020 - the EU Framework Program for Research and Innovation.

In 2004-2020, European Structural and Investment Funds invested 9.1 billion euros in Estonia; another 1.3 million euros of additional investment was attracted by Estonia under the Juncker Plan for the period from 2014 (European Commission, 2019a). The European Fund for Strategic Investments supported 20,808 small and medium-sized enterprises in Estonia. In 2014-2020, Estonia received 140.3 million euros under Horizon 2020/H2020 - the EU Framework Program for Research and Innovation, the largest funding within the Baltic States.

It is worth mentioning that at the end of 2020 a political agreement was reached between the European Parliament and the Council of Europe on a new EU program - Horizon Europe. It is currently the largest transnational program to support research and innovation. Its budget is 95.5 billion euros for the period 2021-2027. Prior to the approval of this program, the two Baltic States (Lithuania and Latvia) voiced the expectation of receiving more from participation in this program, since so far they pay more into the EU research budget than they receive from participating in it (Naujokaityte, 2020).

It must be stated that the above-mentioned program is aimed at financing not democracy, the rule of law, and so on, but strictly science and innovation. Nevertheless, it worth mentioning here that, in determining the amount of funding for member states, the EU has repeatedly voiced a proposal to make this amount dependent on the quality of democracy, the rule of law, and the independence of the judiciary in individual member states. In general, the idea that the amount of funding from EU funds should depend on the respect for the rule of law and other parameters that determine the quality of democracy is increasingly lobbied for. The debate on this issue began in the EU in 2018, when EU finances were positioned as a mechanism to protect the liberal-democratic values of the EU. This had to be an important step in defending its fundamental values. However, we can see that European institutions lack political will and consistency in implementing such a course, and they are not ready for the escalation of conflicts with individual member states.

At this stage, the EU provides less financial and more advisory assistance to the Baltic States. Here is an example. On June 11, 2020, the Parliament of the Republic of Lithuania adopted a new law defining the principles of regional development. As part of the joint project of the 
Council of Europe and the EU "Delivering Good Governance in Lithuania," the bill was scrutinized with a view to establishing its compliance with the EU's legal system. Such consultations are a precautionary measure that helps to prevent future divergences between the EU and individual member states.

The EU has also taken the initiative in recent years to draw the attention of the Baltic governments to specific issues related to destructive phenomena in the socio-political sphere. For instance, in 2018, thanks to the efforts of EU institutions, the risks of money laundering through the banking institutions of the Republic of Lithuania were assessed (Antimoney laundering and counter-terrorist financing measures. Lithuania. Fifth Round Mutual Evaluation Report, 2018). In the context of this case, we stress that EU initiatives on member states that have not fully accomplished democratic transformation are usually a response to the aggravation of existing (usually "chronic") problems caused by the insufficient experience of the democratic organization of state institutions and society in Europe's post-totalitarian regions, such as the Baltic States.

This suggests that the EU should rethink its strategy for strengthening the sustainability of liberal democracy and human rights as soon as possible so that they are consistent with the current threats to democracy. The head of the European Commission, Ursula von der Leyen, rightly formulates the problem of the need for a new format of European democracy; we share her position that European democracies need a new impetus (European Commission, 2019d). As we can see, on the one hand, the position of EU leaders opens up new opportunities for pro-democratic innovation and experimentation; European leaders are constantly emphasizing their readiness to defend and deepen democracy. However, frequent crises of various types in the EU which require an immediate response by European institutions displace the set of tasks regarding the quality of democracy. The EU's authorities and most member states seem to be aware of the importance of strengthening the stability of liberal democracy, but guaranteeing the high quality of European democracy is often a more abstract and less priority goal than strengthening the euro, harmonizing migrant quotas, agreeing the EU budget and so on.

The need for the EU to pay attention to the continuation of democratic reforms in a number of EU regions, including the post-Soviet Baltic States, is due to the fact that three decades after the restoration of independence Estonia, Latvia and Lithuania, having achieved remarkable qualitative changes in their respective national political systems, have not 
completed political transformation and democratic consolidation. The alarming processes in terms of the quality of democracy in the Baltic States are evidenced by scant public confidence in politicians and political institutions; quite frequent changes of government; low voter turnout; low readiness of the population to get involved in political processes; insufficiently strong and active pro-democratic segment of civil society, and so on.

The most obvious problems with the quality of democracy are recorded in Latvia and Lithuania. In contrast, Estonia's democratic progress is more evident, although the electoral success in 2019 of conservative nationalist political forces (EKRE) may in the near future significantly distort the liberal-democratic trajectory of this country's development.

\section{Assessing the Quality of the EU's Efforts to Strengthen Liberal Democracy in Member States}

The question of whether the EU should defend democracy and the rule of law within member states seems a rhetorical one (Müller, 2015). This objective must be modernized in view of those destructive anti-liberal tendencies that are manifested in the reduction, first and foremost, of civil and political rights and freedoms, and the erosion of the principle of pluralism. It is obvious that the EU should take a more careful approach to the audit of liberal democracy in member states, although the fact that there are problems is already evidenced by various indices of democracy and democratization.

A particular problem is that the citizens of most EU countries are dissatisfied with the way democracy works in their countries. Surveys on this topic, which have been regularly conducted for the last half century, testify to this. Certainly, the people of the 21 st century have quite high expectations of the institution of the state and other political actors, and this fact explains the mostly critical assessment of the quality of democracy and the work of democratic institutions. In the context of the global COVID-19 pandemic, the level of criticism of government has risen drastically.

The issue of the democratic deficit in the EU's relations with the citizens of member states is no less relevant. A kind of "abyss" seems often to distance the EU from the problems and expectations of the citizens of member states. Many previous EU efforts to strengthen democracy with- 
in member states have been ineffective. Proof of this can even be seen in the unsuccessful Spitzenkandidaten process in 2019, which was connected with the election of the President of the European Commission. That process became a departure from the transparent and comprehensive decision-making process within the EU, a reason for Euroskeptics to declare the "weakness of the EU" (Fotopoulos, 2019, p. 200). Hence, the question of the quality of democracy in the EU is crucial, as the ability of EU institutions to influence member states and candidate states within the framework of liberal democracy, depends on this.

A number of questions remain open. How to consolidate intra-European democracy, and thus - to reinforce the image of the EU as a democratic community of states? What EU initiatives can help reduce the democratic deficit in member states? How to prevent the situations of democratic regress in potential EU member states after recognizing the fact that the Copenhagen criteria are met? How strong should the EU's control over the standards and values of liberal democracy be, so that such control does not contradict the very principles of democracy and respect for minority rights? What, first of all, should the EU's constructive role consist in, concerning member states, particularly the "young" democracies of the Baltic States, in order to reinforce the quality of national democratic political systems and prevent deviation from the already existing liberaldemocratic progress? This is an open list of questions, the answers to which are in the process of being intensively searched for.

For the time being, we can see that many previous EU projects to strengthen democracy within member states have been ineffective. An example is the European Citizens Initiative. As of the beginning of 2021, only 75 initiatives were registered during the entire implementation of the project, of which only 6 were effective, collecting more than 1 million signatures of citizens (nationals) of the EU member states.

In fact, since the global recession affected the EU, i.e. since 2008, the EU's main achievements have been, above all, relatively effective steps to temporarily curb financial markets, support the single currency, seek compromises between countries on receiving migrants, and so on. Of course, the issues of the quality of democracy were also raised, for example, in the context of the possible activation of Article 7 of the Lisbon Treaty in relation to the states (governments) that receive subsidies, benefits and other preferences of the EU, but violate the rules of coexistence, the values of the EU. The EU has repeatedly voiced proposals to deprive of funding the countries that deviate from the principles of democracy. Thus, 
between 2012 and 2020, the European Commission filed three complaints with the European Court against Hungary and four against Poland, primarily due to attempts by the governments of these countries to subjugate the legislative and judicial branches of government, independent media and non-governmental organizations.

As of mid-2020, the European Court had considered these complaints and delivered a judgement on them (ruling against Hungary and Poland). However, the authorities of the countries on which the EU intends to impose sanctions resorted to a mechanism of vetoing the adoption by the European Parliament of the long-term (seven-year) EU budget for 2021-2027 and a plan to save (recover) the economy 1.830 trillion euros (November 16, 2020). In that way, the Polish and Hungarian governments opposed the interdependence between access to EU money and the observance of the rule of law by a particular member state. It was agreed that the rule of law in the allocation of funds to member states from the EU budget would not apply until the Court of Justice of the European Union established its legitimacy.

This situation raises the question of whether there are enough tools in the EU to bypass the positions of individual member states in making important decisions. It is known that most EU decisions are taken by a qualified majority (support of at least 55 percent of EU member states, which must be home to at least 65 percent of the total EU population). However, a number of issues (including budgetary ones) require unanimity of all member states to make a decision, which is a problem, taking into consideration the obvious differences between EU members. It is clear that the EU needs to improve the political and legal mechanisms that can be used to confront member states which deviate from the standards of European liberal democracy. As a result, the community of liberal democracies of the EU will be able to protect themselves from the need to find a compromise on such important issues as, for example, the rule of law. For the time being, such a tool is a court decision.

Critically assessing the situation with the quality of democracy in the EU, we can state that the EU does not adequately apply sanctions to states which deviate from the legal principles and values of the EU. This could also be a signal to other EU member states, where the stability of liberal democracy is presently being undermined by the actions of illiberal forces. In particular, this applies to the Baltic States, where conservative, nationalist political parties strengthened their positions in the last parliamentary elections. 
It appears that the EU currently does not have the appropriate tools to apply sanctions effectively, or that these tools do exist, but the EU is wary of using them for the sake of the integrity of the European peoples' community. The mechanisms for imposing sanctions on an individual EU member state are simply too complex to apply in practice. Theoretically, a member state of an EU institution can be temporarily deprived of the right to vote in the central bodies of the EU. However, the procedure set out in Article 7 of the Treaty on European Union (the Treaty of Lisbon) is such that it is almost impossible to actually apply. Although the European Council (Summit of Heads of State and Government), at the initiative of $1 / 3$ of EU states, the European Parliament or the European Commission, establishes the facts of violations in the actions of individual member states, at this stage any ally of this violating state can block the further process of bringing it to justice. Furthermore, if an intergovernmental consensus has been reached, the European Council, by the abovementioned qualified majority, may deprive the country of its right to vote. Such a procedure appears to be so complicated that it precludes the effective defense of the values of liberal democracy in the EU.

Clearly, the EU is a cumbersome, institutionally complex structure that is, for the present, unable to find a way out of difficult situations quickly and flexibly. The EU has not yet acquired the image of a stressresistant union. In fact, this was demonstrated by the situation with the member states of the latest "waves" of EU enlargements, which have deviated quite radically from the norms of liberal democracy, adopted by tacit agreement, in the direction of conservative nationalist values. And even the filing of a lawsuit by the European Commission with the European Court is not an effective mechanism, because the states that have their own point of view on the ideological vector of state development are looking for gaps in the legislation to evade sanctions.

Although instruments for the EU to apply pressure to violating states are available, they are misused by the European institutions, inasmuch as EU leaders do not demonstrate the proper political will. For instance, the European Commission could use litigation tools more often, use financial leverage more actively, and so on. There were successful examples of this in the EU: in 2000, when the far-right, populist Freedom Party of Austria (FPÖ) joined the Austrian government, fourteen EU states declared a diplomatic boycott of Austria.

At present, there are no formal obstacles for EU member states to actually freeze (temporarily) diplomatic relations with the authorities of 
states that violate the standards of liberal-democratic development of the EU. Actually, a new relevant instrument could be the EU's right to suspend (defer) payments from the EU budget to countries that do not adhere to the rule of law, but the difficulties of applying such an instrument are obvious. The situation with the approval of the EU budget for 2021-2027 revealed them.

It is evident that if EU states that have already departed from the standards of liberal democracy are not sanctioned for undermining EU values, this will be a clear signal to other member states, including the Baltic States, that an illiberal reversal is acceptable to EU member states. To date, EU institutions have not established themselves as effective guarantors of liberal democratic values. They have not demonstrated the proper political will in requiring member states to abide by their obligations under EU membership. It is possible that this situation is the result of the fact that the EU itself is experiencing a crisis of values. In such circumstances, the "key provisions of EU law are being violated systematically without a meaningful attempt on the part of EU institutions to enforce EU law" (Scheppele, Kochenov, Grabowska-Moroz, 2020, p. 118).

At present, the EU is not active enough in promoting democratic reforms and monitoring the reform of recent enlargements. The level of activity of European institutions needs to be reviewed due to the intensification of ultra-radical political forces which are garnering increasing support from EU voters.

The EU faces an existential crisis and this crisis divides the European community. It is worth noting that in resolving various conflicts between member states which arise on the basis of values, the EU aims above all to prevent open confrontation within. However, such a position does not promote the unity of the member states, but only weakens the capacity of the EU itself, deepening the dividing lines between the member states. While many of the latest challenges call for the growth of solidarity of EU states, some of them appear to view the EU as a source of funding, rather than a value system. Seemingly, the EU wants to save continental unity even at the cost of deteriorating the quality of liberal democracy. To our mind, such a scenario has the prospect of both the reduction of the EU's stability and the constriction of the area of liberal democracy. In fact, the three Baltic States also embraced this pan-European process, which resulted, first of all, in the growth of popularity and the coming to power of illiberal political actors. 


\section{Conclusions}

In recent years, a United Europe has outlined new priorities for its functioning as an integrated community which is focused on the longterm and sustainable perspective (the Rome Declaration of 2017, the Sibiu Declaration of 2019 and other documents). However, the broad range of current tasks of the EU is not sufficiently, in our estimation, aimed at preventing and combating the decline in the quality of democracy, and at the inculcation of the values of liberal democracy. There is a lack of attention to the member states of the recent EU enlargements, where advanced democratic principles have not been the norm for public and private interaction, and thus - creating an obvious risk of regression of democracy. These crucial issues have been supplanted by the actualization of a wide range of security issues, the construction of a responsible migration policy, and, since 2020, the search for ways to mitigate the devastating effects of the COVID-19 pandemic.

We assess the EU's efforts to monitor compliance with the standards of liberal democracy in the member states as ineffective. The EU's ability to act in this direction is undermined not only by numerous external factors (outside the EU), but also by the actions of stakeholders in EU member states who express conservative, nationalist and other attitudes. In fact, the Baltic States are gradually becoming examples (though not the foremost within the EU) of how these attitudes lead to the stagnation or regression of democratic principles and values.

Realizing the ascending nature of anti-liberal processes, the EU's institutions, in our opinion, are not responding properly to the manifestations of democratic regression. Particularly, there is an apparent hesitancy, inconsistency in the application of sanctions to ensure the stability of democracy. Since the time when the threats to the stability of the EU as a liberal-democratic union began to intensify, the policies of the EU institutions towards member states with a clear regression of democracy are not commensurate with the possible consequences of this destructive process.

Most notably, the countries with neo-authoritarian and hybrid regimes receive much more assistance for democratization from the EU than European democracies that have recently joined the EU. The states of the fifth and subsequent enlargements of the EU are currently highlighting the complex vestiges of the totalitarian past which slow down liberal democratization. Understanding the role of the historical factor 
should be an incentive for the EU to implement as many diverse prodemocracy projects as possible in the "young" democracies of Central and Eastern Europe. Instead, since 2004, the EU's attention to the new member states has focused on income equalization, infrastructure development, institutional transformation, and so on, but not on strengthening the values on which the EU is based. According to our estimates, ensuring the high quality of European democracy has become a rather abstract and non-priority goal in comparison with the appreciation of the euro, the harmonization of quotas for the reception of migrants, the adoption of the EU budget and many other issues. Thus, the need to construct a new format of European democracy and mechanisms to guarantee its high quality is obvious.

\section{Bibliography}

Anti-money laundering and counter-terrorist financing measures. Lithuania. Fifth Round Mutual Evaluation Report (2018), MONEYVAL Secretariat, Directorate General of Human Rights and Rule of Law, Council of Europe, Strasbourg.

Council of the EU (2017), The Rome Declaration, https://www.consilium.europa.eu/ en/press/press-releases/2017/03/25/rome-declaration/pdf, 21.08.2020.

Council of the EU (2019), The Sibiu Declaration, https://www.consilium.europa.eu/ en/press/press-releases/2019/05/09/the-sibiu-declaration/\#, 26.09.2020.

European Commission (2019a), Growing together: EU support to Estonia that joined in 2004, https://ec.europa.eu/regional_policy/sources/docgener/factsheet/ eu10_2004/factsheet_growing-together_et_en.pdf, 3.09.2020.

European Commission (2019b), Growing together: EU support to Latvia that joined in 2004, https://ec.europa.eu/regional_policy/en/information/publications/ factsheets/2019/growing-together-eu-support-to-latvia-that-joined-in-2004, 9.08.2020.

European Commission (2019c), Growing together: EU support to Lithuania that joined in 2004, https://ec.europa.eu/regional_policy/en/information/publications/factsheets/2019/growing-together-eu-support-to-lithuania-that-joinedin-2004, 30.09.2020.

European Commission (2019d), Opening Statement in the European Parliament's Plenary Session, https://ec.europa.eu/commission/presscorner/detail/en/ speech_19_4230, 17.09.2020.

Fotopoulos S. (2019), What sort of changes did the Spitzenkandidat process bring to the quality of the EU's democracy?, "European View", vol. 18, no. 2.

Godfrey K., Youngs R. (2019), Toward a New EU Democracy Strategy, Carnegie Endowment for International Peace, Washington. 
Müller J.-W. (2015), Should the EU Protect Democracy and the Rule of Law inside Member States?, "European Law Journal”, vol. 21, no. 2.

Naujokaitytė G. (2020), Baltic states want more out of Horizon Europe, https:// sciencebusiness.net/framework-programmes/news/baltic-states-want-more-outhorizon-europe, 22.10.2020.

Raine S. (2019), Europe's Strategic Future: From Crisis to Coherence?, Routledge for the International Institute for Strategic Studies, Abingdon, UK.

Scheppele K. L., Kochenov D., Grabowska-Moroz B. (2020), EU Values Are Law, after All: Enforcing EU Values through Systemic Infringement B. Actions by the European Commission and the Member States of the European Union, https:// academic.oup.com/yel/advance-article/doi/10.1093/yel/yeaa012/6064852? searchresult $=1,05.01 .2021$.

\section{Polityka UE dotycząca pogłębienia liberalnej demokracji: przykład państw baltyckich}

\section{Streszczenie}

Badana jest skuteczność działań UE w zakresie jakości demokracji w państwach członkowskich. Na przykładzie Estonii, Łotwy i Litwy oceniano skuteczność unijnych projektów dotyczących kontynuacji transformacji liberalno-demokratycznej w państwach członkowskich z przeszłością posttotalitarną, w których utrzymuje się ryzyko regresu demokracji. Obecne cele UE scharakteryzowano jako niedostatecznie ukierunkowane na odpowiednie zapobieganie i przeciwdziałanie spadkowi jakości demokracji, zakorzenienie wartości demokracji liberalnej. Konieczność zintensyfikowania działań UE w kierunku monitorowania przestrzegania standardów demokratycznych tłumaczy się stagnacją/regresją jakości demokracji w krajach ostatnich rozszerzeń UE, w tym w państwach bałtyckich. Działania instytucji UE wobec państw członkowskich, w których demokracja znajduje się w stagnacji/regresie, zostały ocenione jako niezgodne z możliwymi konsekwencjami tego destrukcyjnego procesu. Podkreśla się brak zainteresowania UE umacnianiem wartości, na których opiera się UE, co jest postrzegane jako główna przyczyna obecnego pogorszenia się jakości demokracji. Podkreślono potrzebę skonstruowania nowego formatu demokracji europejskiej, nowych mechanizmów gwarantujących jej jakość.

Słowa kluczowe: demokracja liberalna, państwa bałtyckie, UE, wady demokracji, jakość demokracji 
